\title{
Paremata Redoubt: colonial follies
}

\author{
Pamela Chester, PIC Archaeology \& Palynology, Wellington
}

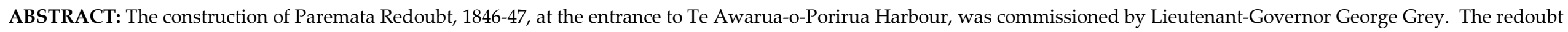

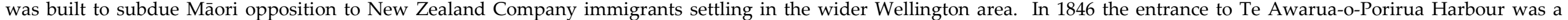

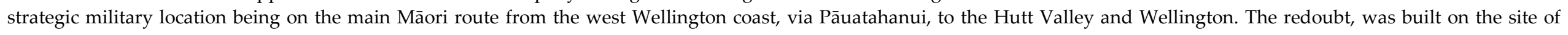

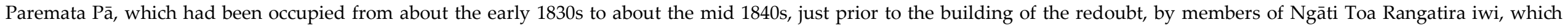

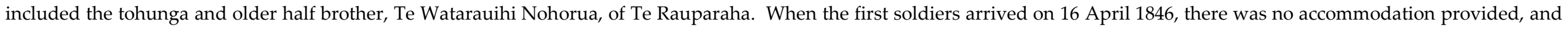

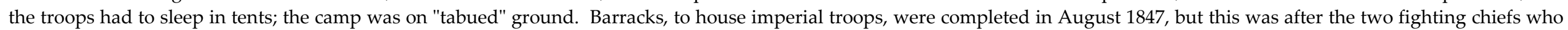

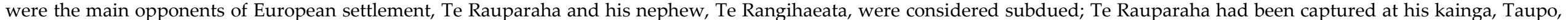
on Plimmerton beach and Te Rangihaeata had fled northwards from his pā, Mataitaua, at Pāuatahanui.

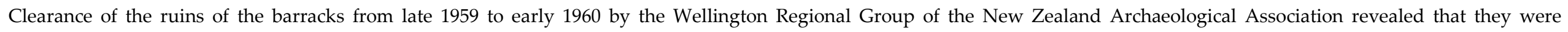

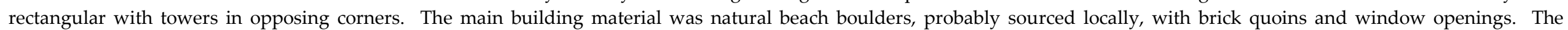

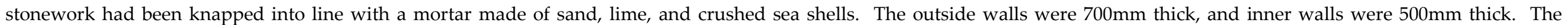

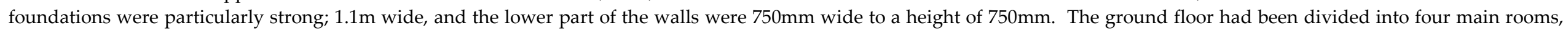

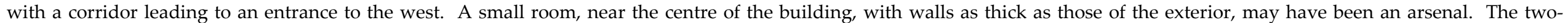

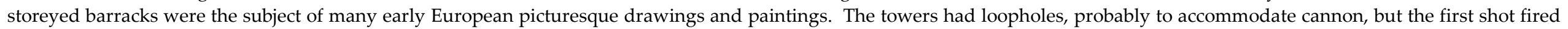

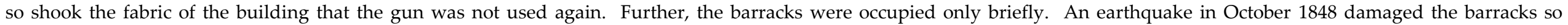

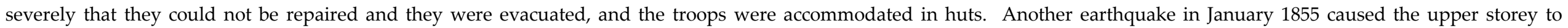
collapse. Today the ruins of the barracks can be seen in Ngātitoa Domain.

At Paremata Point, on the west coast of Wellington, near the shoreline of the narrow inlet channel dividing the maritine outer from the estuarine double-armed inner Te Awaruao-Porirua Harbour, are the remains of the barracks of Paremata Redoubt constructed 1846-47. ${ }^{1}$ In early July 1848, Reverend Richard Taylor wrote in his journal: "The first view of the barracks at Porirua point was very beautiful and strongly reminded me of the

\footnotetext{
${ }^{1}$ New Zealand Historic Places Trust "The Register" n.p.
}

Castle of Chillon on the lake of Geneva" 2 (Figure 1). On the other hand, in $1852 \mathrm{Lt}$ Colonel Godfrey Charles Mundy described the area where the barracks were built as "the very dreariest - the only dreary spot in the circuit of the harbour - a sandy flat commanding its entrance."3

The barracks were built by the colonial

2 Taylor Journal of Rev. Richard Taylor (July 1848) V:234.

${ }^{3}$ Mundy Our Antipodes p 333. government to house Imperial troops. ${ }^{4}$ The ruins of the barracks are historically and culturally significant and of value to our New Zealand heritage as they date to the early European colonial period, and the genesis of our distinct predominantly Māori/European society, and were associated with some of the first conflicts between the two cultures. Noteworthy, is that nationally, they are one of

${ }^{4}$ Grey "Extract from a Letter of His Excellency the Governor to Major Last dated Wellington 21 April/46." 
two European fortifications constructed between 1840 and 1848 with extant standing structures, and one of three with remnant surface evidence. ${ }^{5}$ Thirty-two fortifications are known to have been built in the first eight years of Crown rule, thus the ruins of the barracks at Paremata Point are an extremely rare and important representation of that period. ${ }^{6}$

Paremata Redoubt has been recorded by Heritage New Zealand Pouhere Taonga (previously known as New Zealand Historic Places Trust, NZHPT), which was established by section 9 of the Heritage New Zealand Pouhere Taonga Act 2014, on the Heritage New Zealand List/Rārangi Kōrero. The Heritage New Zealand List/Rārangi Kōrero ("the List") identifies New Zealand's significant and valued historical, cultural, and ancestral places. "The Register" of the former NZHPT has been continued under the Heritage New Zealand Pouhere Taonga Act 2014, and is maintained by Heritage New Zealand Pouhere Taonga. "The List" is the same as "the Register" established under

${ }^{5}$ Walton "New Zealand redoubts, stockades and blockhouses, 1840-1848" pp 11-12.

${ }^{6}$ Walton "New Zealand redoubts, stockades and blockhouses, 1840-1848" p 14.

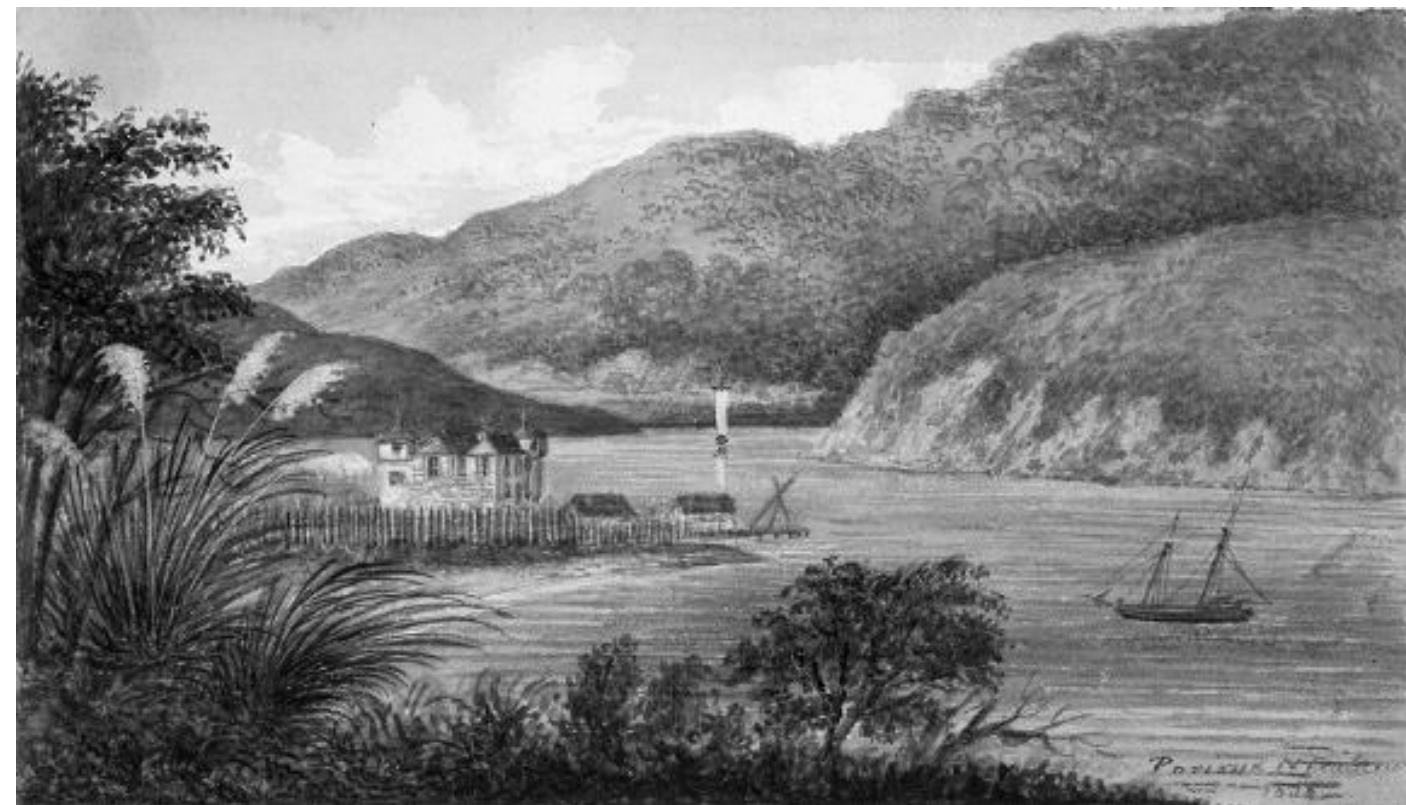

Figure 1: Paremata Redoubt painted [original in watercolour] in 1858 by Charles Emilius (Lieutenant-Colonel) Gold. Paremata Barracks are shown as a castle-like stone building, at Paremata Point. Part of: Gold, Charles Emilius 18091871: Sketches by General Gold, 1846 to 1860. A-288-014, Alexander Turnbull Library, Wellington, New Zealand, http://natlib.govt.nz/records/22886705.

Section 22 of the Historic Places Act 1993. All entries on "the Register" immediately prior to the commencement of the Heritage New Zealand Pouhere Taonga Act 2014, in May 2014, were deemed to be entries on "the List." "The List" is the only national statutory record of our heritage places, and is an information tool that identifies and provides information on significant heritage places throughout New Zealand, including for the purposes of the
Resource Management Act 1991. "The List" identifies:

1) Historic places - such as archaeological sites, buildings, memorials

i) Category 1: places of special or outstanding historical or cultural heritage significance or value

ii) Category 2: places of historical or cultural heritage significance or value

2) Historic areas - groups of related historic places such as a geographical area with a number of properties 
or sites, a heritage precinct or a historical and cultural area

3) Wāhi tūpuna - places important to Māori for ancestral significance and associated cultural and traditional values

4) Wāhi tapu - places sacred to Māori in the traditional, spiritual, religious, ritual or mythological sense such as maunga tapu, urupā, funerary sites and punawai

5) Wāhi tapu areas - areas that contain one or more wāhi tapu. $^{7}$

Paremata Barracks are entered on the New Zealand Heritage List/Rārangi Kōrero as a Category 2 historic place (register number 1329). ${ }^{8}$ Unfortunately, entry on "the List" does not afford automatic protection for our heritage, nor does it directly create regulatory or legal obligations on property owners or create specific rights or control over property, but can lead to heritage properties being considered for inclusion in district plan heritage schedules of local authorities, which may contain additional rules that provide protection for our heritage.

Ngatitoa Domain, where the ruins of the Paremata Barracks stand, is currently a Recreation Reserve owned by the Crown and

${ }^{7}$ Heritage New Zealand Poutere Taonga Act 2014 s 6. ${ }^{8}$ Heritage New Zealand "The List/Rārangi Kōrero: Paremata Barracks Ruins [no. 1329]" n.p. controlled by the City of Porirua. Porirua City records significant historic heritage buildings and sites identified in accordance with: historic values; social values; setting and group values; architectural values; scientific and technological values; Māori cultural values; and archaeological values. Buildings and sites are grouped according to their relative significance into one of the following categories:

i) Historic Heritage Group A: Buildings that have outstanding national or regional significance due to their "rarity" and/or level of "integrity."

ii) Historic Heritage Group B: Buildings that have regional or local significance.

iii) Historic Heritage Sites: Places and areas that are of national, regional and/or local significance. ${ }^{9}$

Paremata Barracks are listed in "Buildings Group A" (HHA012). ${ }^{10}$ Porirua City has developed a number of rules for the protection of historic heritage buildings in categories "A" and "B" that are additional to any other relevant zone rules and standards. ${ }^{11}$

${ }^{9}$ Porirua City District Plan "Plan Change 15: Historic Heritage" pp 4-5.

${ }^{10}$ Porirua City District Plan "Plan Change 15: Historic Heritage" p 18.

${ }^{11}$ Porirua City District Plan "Plan Change 15: Historic Heritage" pp 11-14.
Furthermore, the Paremata Redoubt (/Paremata Barracks) is recorded as an archaeological site on the national inventory of archaeological sites. ${ }^{12}$ It is site number R26/254. Archaeological sites are defined in the Heritage New Zealand Pouhere Taonga Act 2014 as:

(a) any place in New Zealand, including any building or structure (or part of a building or structure), that -

(i) was associated with human activity that occurred before 1900 or is the site of the wreck of any vessel where the wreck occurred before 1900; and

(ii) provides or may provide, through investigation by archaeological methods, evidence relating to the history of New Zealand; and

(b) includes a site for which a declaration is made under section 43(1). Section 43(1) states that Heritage New Zealand Pouhere Taonga may, on reasonable grounds, declare any place to be an archaeological site if the place:

(i) was associated with human activity in or after 1900 or is the site of the wreck of any vessel where that wreck occurred in or after 1900; and

(ii) provides, or may be able to provide, through investigation by archaeological methods, significant evidence relating to the historical and cultural heritage of New Zealand.

As an archaeological site, the ruins are afforded protection as the modification or destruction of an archaeological site is

${ }^{12}$ Archsite 2010 n.p. 
prohibited, unless an authority is obtained from Heritage New Zealand Pouhere Taonga under the Heritage New Zealand Pouhere Taonga Act 2014; no person may modify or destroy, or cause to be modified or destroyed, the whole or any part of a site if that person knows, or ought reasonably to have suspected, that the site is an archaeological site. Today the barracks remnants are visible above ground surface. They are fenced for protection, and sign-posted as an historic tourist attraction.

Despite the current recognition of the significance and value of the barracks to our cultural and historical heritage, their beginning was not auspicious. The construction of the barracks was commissioned by Governor George Grey. ${ }^{13}$ George Grey was appointed governor of New Zealand, by the British Crown, in December $1845,{ }^{14}$ and arrived in Wellington the following February. ${ }^{15}$ He commissioned the construction of Paremata Redoubt as part of a wider distribution of Imperial military installations in the Porirua and Wellington

${ }^{13}$ Grey "Extract from a Letter of His Excellency the Governor to Major Last dated Wellington 21 April/46."

${ }^{14}$ Bassett "Impotent Autocrats 1840-1860" p 64.

${ }^{15}$ Burnett The Paremata Barracks p 12. district $^{16}$ to subdue Māori opposition to New Zealand Company immigrants settling in the wider Wellington area, to prevent obstruction of building a road from Wellington northwards along the west coast, and maintain peace between Māori and European. ${ }^{17}$ An immediate concern was to form a military protection line for the Wellington district from Porirua to Upper Hutt during the winter of 1846, and to achieve this he wanted to station 220 men from various regiments, and 25 policemen at Paremata Point. ${ }^{18}$ Disputes in the mid 1840s between Māori and New Zealand Company settlers, had resulted in several deaths on both sides, and there was fear of further conflict. ${ }^{19}$ In 1846 the entrance to Te Awarua-o-Porirua Harbour was a strategic military location as it was on the main Māori overland route from the west Wellington coast, via Păuatahanui, to Hutt Valley and Wellington. ${ }^{20}$ Te Awarua-oPorirua Harbour was an assembly point and a

${ }^{16}$ Best "Old Redoubts, Blockhouses, and Stockades of the Wellington District" pp 14-28.

${ }^{17}$ Grey "The occupation of Porirua by the Military, Completion of Roads."

${ }^{18}$ Grey "Secret. Memorandum" pp 817-839.

${ }^{19}$ Waitangi Tribunal "Te Whanganui a Tara" pp 58-60.

${ }^{20}$ Grey "Secret. Memorandum" p 825; Grey "The

occupation of Porirua by the Military, Completion of Roads." shelter for canoes, and a sanctuary after raids. ${ }^{21}$

Paremata Redoubt was built at Paremata Point, on the site of Paremata Pā. "Parhamatta Pah" is written on a detail plan on survey office plan 10505 (SO 10505), drawn by the government surveyor TH Fitzgerald in 1843, ${ }^{22}$ immediately to the east of the land claimed by Joseph Thoms, whose shore-based whaling station had been set up beside Paremata Pā, on the west side of the point. A plan of the government reserve at Paremata Point, drawn by TB Collinson on 21 March 1848 and certified by TH Fitzgerald on 27 March 1848, shows the barracks within the reserve. ${ }^{23}$ The barracks are drawn to the east of the land claimed by Mr Thoms, in the location marked "Parhamatta Pah" on the plan drawn by Fitzgerald in 1843. The former location of Paremata Pã is indicated on the plan drawn in 1848 by two notes written to the west of the "Barrack yard" stockade, which state: "Old Post of Native pa of totara." Paremata Pā had

${ }^{21}$ Wakefield Adventure in New Zealand II:243; Burnett The Paremata Barracks p 14.

${ }^{22}$ Fitzgerald "Sketch plan shewing Tom's claim" n.p.

${ }^{23}$ Collinson "Plan-of The Government Reserve at Paramatta-Point Near Wellington New Zealand" 
been occupied from about the early $1830 \mathrm{~s}^{24}$ to about the mid 1840s, just prior to the building of the redoubt, by members of Ngāti Toa Rangatira iwi, which included Te Watarauihi Nohorua, a Tohunga Rangatira, who founded the pā. ${ }^{25}$ Te Watarauihi Nohorua was Te Rauparaha's older half brother. ${ }^{26}$ The two chiefs, Te Rauparaha and his nephew Te Rangihaeata were the main opponents of European settlement. ${ }^{27}$

Imperial regiments first occupied Paremata Point on Thursday 16 April 1846. ${ }^{28}$ Major Last, and about 260 troops of the 58th and 99th regiments, were conveyed from Wellington to Paremata Point on board the frigate HMS Calliope and the steam frigate HMS Driver. ${ }^{29}$ Gale-force winds prevented them from landing for five days. Another detachment of the 99th regiment, that traveled overland, arrived the same evening. When

${ }^{24}$ Waitangi Tribunal "Te Whanganui a Tara" p 26.

${ }^{25}$ Fordyce The Pa of Porirua 1830-1850

${ }^{26}$ Ballara "Te Whanganui-a-Tara" p 17; Ngāti Toa

Rangatiraet al. Deed of Settlement Schedule: Documents $\mathrm{p}$ 42.

${ }^{27}$ Burnett The Paremata Barracks.

28 "The Wellington Independent: Wednesday, April 22, $1846 "$ p 2.

29 "Military movements connected with Rangihaeata" $\mathrm{p}$ 3. the soldiers arrived, there was no accommodation provided for them. The troops encamped near "Toms" fishery, on a neck of land abuting the Bay."30 McKillop, midshipman on the Calliope said:

We disembarked the troops we had brought round, and left them on a flat point of land with their tents, which were in very bad condition, to encamp themselves, and to cut off the communication between Rangy [Te Rangihaeata, now living at his pā, Mataitaua, at Pāhuatahanui where St Alban's Church stands today] and the natives on the coast, who were supplying him with provisions. The piece of ground on which they were encamped having been tabued, or made sacred, rendered it highly probable that they would be attacked before they had time to fortify themselves, which they did at first by digging a trench round their front meeting the sea on either side, which protected their rear; but finding that twice the number of men which they could muster would not have filled it, that mode of fortification was abandoned, and a stockade contemplated. ${ }^{31}$

The soldiers built huts for themselves of fern, flax, and reeds and were for some weeks engaged in felling timber, dragging it through the bush to the water's edge, and rafting it to

30 "The Wellington Independent Wednesday, April 22, $1846 "$ p 2.

${ }^{31}$ McKillop Reminiscences of twelve months' service in New Zealand pp 183-184. the camp. ${ }^{32}$ Land communication with Wellington was by a "forest path, so bad and impracticable, that all supplies had to be sent round by sea." 33

After the seizure of Te Rauparaha on 23 July at his pā, Taupo, on the beach at Plimmerton and his detention on HMS Calliope and before the assault on Te Rangihaeata's Pā at Pāhuatahanui in early August, McKillop says that he was "left behind when the ship returned to Wellington"34 to collect recruitments,

not exactly knowing how we were to avoid coming to blows if we endeavoured to cut off their supply of provisions, or to make any of them prisoners. ${ }^{35}$

Major Last, 99th regiment, had left one hundred men at Paremata Point as reinforcements. ${ }^{36} \quad$ McKillop continues "however, the day after the ship left, we took one of their canoes coming down for

32 Burnett The Paremata Barracks p 15.

${ }^{33}$ Power Sketches in New Zealand pp 14-15.

${ }^{34}$ Ngati Toa Rangatira et al. Deed of settlement of Historical Claims [signed 7 December, 2012] pp 27-28; "Official account of the capture of Rauparaha" p 106.

${ }^{35}$ McKillop Reminiscences of twelve months' service in New Zealand pp 185-186.

36 "Official account of the capture of Rauparaha" p 106. 
provisions."37

\section{On 31 July 1846}

a detachment of fifty of the Hutt Militia, under the command of Messrs. McDonogh and White, a party of thirteen of the Police under Mr. A. Strode, and 150 natives, left the Hutt District, to proceed to Porirua by the track which the rebels generally travelled over in their incursions in that District. The detachment were accompanied by Ensign Middleton of the 58th regiment, and Messrs. Ludlam and Stilling as volunteers. ${ }^{38}$

They were heading for Te Rangihaeata's pā at Pāuatahanui. However, when they arrived they found the pā had been evacuated. ${ }^{39}$ A nor'-wester in Cook Strait had delayed the Calliope, which was carrying detachments of the 65th and 58th regiments to Paremata Point for an advance on Te Rangihaeata's pā from that side. When they arrived at $\mathrm{Te}$ Rangihaeata's pā, they found it already occupied by the other force. The entire force, except those left to garrison Pāuatahanui, returned to Paremata Point. On 3 August the combined force advanced up the Horokiri

${ }^{37}$ McKillop Reminiscences of twelve months' service in New Zealand $\mathrm{p} 186$.

38 "New Zealand Spectator, and Cook's Strait Guardian. Saturday, August 1, 1846" p 2.

${ }^{39}$ Burnett The Paremata Barracks p 19.
Valley in pursuit of Te Rangihaeata, ${ }^{40}$ and supplies were sent from Paremata Redoubt. ${ }^{41}$ But Major Last, as the senior officer, soon withdrew to Paremata Point and left a Māori force with European advisers to pursue Te Rangihaeata. ${ }^{42}$ The militia were disbanded at the end of September, but the imperial troops stayed on. ${ }^{43}$

WT Power, Deputy Assistant Commissary General, arrived at Paremata Point camp in August 1846, after the group from the camp including Major Last, Captain Stanley, Captain Durie (of the militia), McKillop, and some Armed Police had seized Te Rauparaha, and also after Te Rangihaeata had evacuated his pā at Pāuatahanui and retreated northwards through the Horokiri Valley to Horowhenua subsequent to being harassed by McKillop and others stationed at the camp at Paremata Point. ${ }^{44}$ McKillop had had a ship's

${ }^{40}$ Burnett The Paremata Barracks p 19.

41 "Official account of the capture of Rauparaha" p 106; McKillop Reminiscences of twelve months' service in New Zealand

42 Burnett The Paremata Barracks p 19.

${ }^{43}$ Burnett The Paremata Barracks p 20.

44 "Official account of the capture of Rauparaha" p 106; "The Wellington Independent, Saturday, September 12, $1846 "$ p 2; McKillop Reminiscences of twelve months' service in New Zealand; Power Sketches in New Zealand with pen long-boat converted into a gun-boat by mounting a 12-pound carronade and borrowing a brass gun. The boat was made bullet-proof by "lashing the men's beds up in their hammocks and fastening them round the boat."45 Swainson the son of a Hutt Valley settler, who was stationed at Paremata Redoubt and served under McKillop, said that McKillop was fearless. ${ }^{46}$

Power described the camp as "a slight stockade round small reed huts in which officers and men live, without chairs and tables, and with only a couple of blankets for a bed: this in a dry climate might be well enough, but there, where it has poured incessantly for six weeks, it is no joke." 47 It was:

completely exposed to the violent gales which are very frequent at this season ... exposed to rain and wind, with coarse fare and coarser lodging, my clothing ill adapted to the climate, ... was a most uncomfortable though not an unexciting scene, from the constant arrivals and

and pencil.; Ward Early Wellington $\mathrm{p}$ 426; Ngati Toa Rangatira et al. Deed of settlement of Historical Claims p 28; Reilly Pāuatahanui p 33.

${ }^{45}$ McKillop Reminiscences of twelve months' service in New Zealand p 194.

${ }^{46}$ Swainson William Swainson

${ }^{47}$ Power Sketches in New Zealand with pen and pencil $\mathrm{p} 12$. 
departures, rumours of war, alarming reports, the anxiety for news from the outposts, the numerous shifts and resources to employ time and extract amusement from such limited resources, and the ingenuity required to supply the commonest wants. In the evening thirtysix of us sat down to dinner, consisting of native beef, biscuit, and rum. Our utensils were tin and pewter plates and tin cups, which latter served alternately to contain the soup, the grog, and the coffee. He was a lucky man who had knife, fork, and spoon, very few had all three, some none at all; and these last fared badly in the general scramble, and met with but little pity or assistance from their more fortunate neighbours. ${ }^{48}$

On 28 April 1846, twelve days after the first troops arrived, tenders were called by the government, up to the 18th May, for the erection of military barracks to be made of stone at the entrance to Porirua Harbour. TH Fitzgerald, who had previously surveyed this area, was the architect. ${ }^{49}$ The first stone of the building was laid on Friday, 23rd October 1846, by Captain Armstrong, the officer in command at Porirua. ${ }^{50}$ This was almost three months after Te Rauparaha and $\mathrm{Te}$ Rangihaeata had been subdued. But it was not until 7 August 1847 that the completed

${ }_{48}$ Power Sketches in New Zealand with pen and pencil pp 12-13.

49 "Government Notice" p 2.

${ }^{50}$ Best "Old Redoubts, Blockhouses, and Stockades of the Wellington District" p 22 barracks were delivered over by Mr Wilson, the contractor, to the Ordnance Department. ${ }^{51}$ This was nine months after the first stone was laid, 16 months after the first imperial troops had arrived, and more than a year after Te Rauparaha and Te Rangihaeata, was considered subdued.

On 27 May 1846 the strength of the force stationed at Paremata Point was: 78 men of the 58th regiment under Captain Laye and Lieutenant Pedder; 74 men of the 99th regiment under Captain Armstrong and Lieutenant Elliot, who were under the command of Major Arney; 9 Royal artillery men under Lieutenant the Hon. A Yelverton; and 25 Royal Marines from HMS Calliope under Lieutenant Fosbrooke.52 Governor Grey wanted to build:

A Good Barrack for fifty men, which can squeeze one hundred men shall be built for you [Major Last] without delay. I think it had better be a comfortable Brick Barrack and not a Block house. ${ }^{53}$

51 "New Zealand Spectator, and Cook's Strait Guardian. Saturday, August 14, 1847" p 2.

52 "New Zealand Spectator, and Cook's Strait Guardian. Wednesday, May 27, 1846" p 2.

${ }^{53}$ Grey "Extract from a Letter of His Excellency the Governor to Major Last dated Wellington 21 April/46."
There were problems at the beginning of construction of the barracks, which delayed progress. When trenches were dug for the foundations, instead of the gravel substrate that the architect had expected, which would have provided secure support for the foundations, the contractor found a continuation of the surface sand, so the foundation specifications were changed, and timber provided for the superstructure was used to strengthen the foundations. ${ }^{54}$ The contract was to have been completed by 9 January 1847, but on 8 February 1847, TH Fitzgerald wrote to the Superintendent in Wellington soliciting an extension of the completion date. Apart from the additional work required on the foundations, windy weather had hindered getting the stone for the building across the harbour in boats. The contract was extended to 28 April 1847, as requested. ${ }^{55}$

Unfortunately, the original drawings for the barracks have not been found. Early illustrations of the barracks, for example,

${ }^{54}$ Burnett Paremata Barracks p 17; Fitzgerald "Enclosing a letter from James Wilson relative to the completion of Porirua Barracks."

${ }^{55}$ Fitzgerald "Soliciting extension of leave for Mr Wilson to complete the barracks at Porirua." 
Figure 1 and pencil drawings by William Swainson and his son William John drawn about $1847^{56}$ and GC Mundy in January $1848^{57}$ image a two-storey building with towers at opposite corners, northwest and southeast that are three storeys high, one storey higher than the main structure. A contemporary report describes the barracks as two storeys high, with two feet $[0.6 \mathrm{~m}]$ thick rubble stone walls, brick quoins and window openings, and four internal partition walls. ${ }^{58}$ The architect reported that he had complied with instructions to "provide a building for constant occupation of 50 men and their Officers and large enough that 100 might sometimes be accommodated in it." 59 He had allowed for the constant residence of three officers upon the supposition that a medical gentleman would always accompany a detachment stationed there, and thought it would be impossible for "any number of natives to surprise or take it, if it contained but 20 or 30 men well supplied with

${ }^{56}$ Swainson and Swainson Paremata Redoubt drawn about 1847.

${ }^{57}$ Mundy "Military Post on Porirua Harbour."

${ }^{58}$ Collinson "Report of the Earthquake of October 1848, at Paremata Point, Porirua, near Wellington."

${ }^{59}$ Fitzgerald "Plans and specifications of the Military Barracks at Porirua." ammunition." The upper stories of the towers would command every point about the building, and the surrounding country and harbour, particularly if small cannons were installed in them. On the other hand, the defenders would be safe provided canon were not fired against them. It was planned that the stockade around the barrack would be an open one, in Māori-style, intended merely to prevent a sudden rush upon the sentries. The cost of the building had been reduced by using mostly stone in lieu of the originally proposed brick. The architect was optimistic that if the barrack was built according to the plans, in a substantial and permanent manner, in a few years time should the government no longer require a detachment of troops there, that there would be no difficulty in obtaining the full value for it from persons desiring to convert it into an hotel.

The contractor had suffered financial $\operatorname{loss}^{60}$ caused not only because of the additional work required for the foundations, but also because he had to pay a higher price for timber to replace that which he had used in the foundations. Further, because there were

${ }^{60}$ Wilson "Requesting payment for completion of barracks." delays in the work while new specifications were being drawn-up, the sawyers who he had engaged left without notice and went to work elsewhere for the government, and he had difficulty replacing them and caused a loss in carpenter's wages. The delay also forced him to work during a period of the year of unfavourable weather. ${ }^{61} \mathrm{He}$ needed to be paid promptly at the completion of the contract so that he could pay his tradesmen. ${ }^{62}$

The architect, TH Fitzgerald, supported the contractor's applications for extensions, ${ }^{63}$ recommended that a penalty not be imposed for the late completion date, arranged for the final payment to be paid early, and even praised his workmanship, ${ }^{64}$ but the construction was poor. A note to Grimstone from JE Eyre (Lieutenant-Governor of New Munster) (on the back of a letter written by

${ }^{61}$ Fitzgerald "Enclosing a letter from James Wilson relative to the completion of Porirua Barracks."

62 Wilson "Requesting payment for completion of barracks."

${ }^{63}$ Fitzgerald "Soliciting extension of leave for Mr Wilson to complete the barracks at Porirua."

${ }^{64}$ Fitzgerald "Enclosing a letter from James Wilson relative to the completion of Porirua Barracks;"

Fitzgerald "Enclosing a letter from James Wilson that the payment of $£ 350$ may be made;" Fitzgerald "Possession of the receipt from the Acting Barracks Master." 
the architect to SE Grimstone, the Acting Secretary, Wellington, requesting that the Lieutenant-Governor conduct an enquiry into the origin of the late fire at Porirua Barracks), requested Grimstone to write to Fitzgerald and inform him that an investigation into the cause of the fire had already been made and that it occurred through "the gross misconstruction of the fireplace the back of which was only one brick thick ... bricks were ... resting against the flooring joists and boards of the back rooms." ${ }^{65}$ He further stated that:

such great negligence in the building of the fire place so near to a powder magazine is most reprehensible ... might have caused as it very nearly did cause the most fearful loss of life and property.

It is said that the towers had loopholes, ${ }^{66}$ but the first shot fired from a cannon so shook the fabric that the gun was not used again. ${ }^{67}$

In October 1847, when Power "went out to our old post at Porirua for a few days," he "found great changes there. ... and, in place of our

${ }^{65}$ Fitzgerald "Calling for an investigation on the origin of the fire at Porirua Barracks."

${ }^{66}$ Burnett Paremata Barracks p 17.

${ }^{67}$ Best "Old Redoubts, Blockhouses, and Stockades of the Wellington District" p 22 miserable warres and stockade, there is now a fine stone barrack, with capital officers' quarters and mess room."68 But while the barracks were occupied, out buildings were constructed. A plan drawn in March 1848, ${ }^{69}$ shows two cottages of wattle and daub, two clay cottages, a canteen, a field magazine, commissariat store, a guard house, a cookhouse, and a pigsty. Two privies and a well are also indicated close to the barracks. Some structures especially a lime kiln, $\mathrm{Mr}$ Wilson's timber house, and Wilson's wharf may be remnants of buildings associated with the construction of the barracks.

The barracks were occupied only briefly. In October 1848 a series of earthquakes occurred over several days. ${ }^{70}$ The first shock occurred on Monday at 1:30 am on 16 October, and lasted about a minute. The building was cracked at almost all the junctions between stone and brickwork from the top nearly to the bottom. The second shock occurred on

\footnotetext{
${ }^{68}$ Power Sketches in New Zealand with pen and pencil $\mathrm{p} 120$. ${ }^{68}$ Swainson William Swainson F.R.S., F.L.S.: Naturalist $\mathcal{E}$ Artist: family letters $\mathcal{E}$ diaries, 1809-1855.

${ }^{69}$ Collinson "Plan-of The Government Reserve at Paramatta-Point."

${ }^{70}$ Grapes \& Holdgate "Earthquake clustering and possible fault interactions across Cook Strait" p 312.
}

Tuesday afternoon. It was not as violent as that of the first, but it opened and extended the existing cracks and cracked the east side of the main wall. The third shock occurred on Thursday morning and was more violent than that of the second. It cracked the partition walls in the upper storey at the junction with the main walls and on each side of the large doorways, and most of the brick arches over the doors. The worst cracks were on the east side. Further lighter shocks increased the cracks. Collinson thought that if there were no more shocks, the building was not in danger of falling down, with the exception of the southeast tower, which had numerous cracks. However, he considered that it would never again be safe for habitation because the bonds at the angles were so broken that no repairs could secure the brick and stonework. Collinson therefore recommended that it be taken down and the materials sold. He estimated that the timber and bricks, and other materials would be worth about $£ 250$. However, he recommended that it not be taken-down immediately as the cost of labour was very expensive at that time. Rather, it should be locked up and used as a powder magazine by the Ordnance, as long as the troops remained there. He recommended that 
the troops be accommodated in huts. ${ }^{71}$

But once the Pāuatahanui Station was abandoned as a military outpost in 1850, the only military outpost maintained in the neighbourhood of Wellington was that at Paremata Point. ${ }^{72}$ A plan of Paremata Barracks surveyed by VD McManaway in $1852^{73}$ shows the positions of the stone barracks and associated buildings. In comparison with the plan drawn in $1848,{ }^{74}$ the stockade now encloses the commissariat and the former "field magazine," now a "Guard Room." Mr Wilson's house is no longer indicated, but three structures are shown inside the northern boundary of the stockade fence, close to the well. The stockade fence surrounds the barracks on all sides apart from the water-front, and a gate is shown on the west side. The canteen is still shown in the same position outside the stockade fence and a bakery is shown to the northeast of the fence. The imperials retained possession until

${ }^{71}$ Collinson "Report of the Earthquake of October 1848, at Paremata Point, Porirua, near Wellington."

72 Ward Early Wellington p 154; Healy "Pauatahanui Inlet: an environmental study" p 21.

${ }^{73}$ McManaway MapColl 832.47hkcmf 18524443.

${ }^{74}$ Collinson "Plan-of The Government Reserve at Paramatta-Point." 1st June 1852.75 At the time of closure there were outbuildings recorded - a guardhouse, separate kitchens for the officers and men, a cleaning shed, and a commissariat store valued at $£ 440 .{ }^{76}$

Further large earthquakes occurred in January and February 1855. ${ }^{77}$ Fortunately, the barracks had been unoccupied since mid 1852 .

In late 1959 to early 1960, remnants of foundations and lower walls of the barracks were cleared of debris by the Wellington Regional Group of the New Zealand Archaeological Association. ${ }^{78}$ It was found that the barracks were rectangular, $18.3 \mathrm{~m}$ by $13.4 \mathrm{~m}$, with towers in opposing corners (NW and SE). The main building material was natural beach boulders, with brick quoins and window openings. The stonework had been knapped into line with a mortar made of sand,

${ }^{75}$ Office of Ordnance [signatures illegible] "Office of Ordnance requesting that the Military buildings at Porirua may be surveyed and amount paid to Ordnance."

${ }^{76}$ Fitzgerald "Requesting further investigation as to the valuation of Porirua Buildings."

77 Grapes \& Holdgate "Earthquake clustering and possible fault interactions across Cook Strait" p 312.

${ }^{78}$ Davis "A Note on the Excavation of the Barracks at Paremata" p 25 lime, and crushed sea shells, which was soft and crumbly at the time of the clearance. Burnett states that "it was standard practice at the time to use shells for lime and to assume that sand on or near the beaches would be free from salt traces in any quantity."79 Thus implying that shells and sand from the local beach were used in the construction of the barracks. Since limestone sources were not close at hand, Burnett assumes that seashells available on the local coast were baked "in a primitive kiln, crushed"80 roughly, and then the lime slaked before adding it to the rest of the mixture. It is possible that the failure of the mortar to last was caused by hurried or imperfect slaking, mixing with water to produce hydrated lime (calcium hydroxide). ${ }^{81}$ A three-sided structure in the southeast corner of the government reserve at Paremata Point is labeled "Lime kiln." 82 Bricks were made on site. ${ }^{83}$ In 1960 the bricks were found to be soft

\footnotetext{
${ }^{79}$ Burnett Paremata Barracks p 18.

${ }^{80}$ Burnett Paremata Barracks p 18

${ }^{81}$ Burnett Paremata Barracks p 18.

${ }^{82}$ Collinson "Plan-of The Government Reserve at

Paramatta-Point Near Wellington New Zealand, being part of Section No. 81 Porirua District."

83 "The Wellington Independent, Saturday, September

12, 1846" The Wellington Independent (12 September 1846)
} 
and crumble easily. ${ }^{84}$

Patches of exterior plaster were present. The outside walls were $700 \mathrm{~mm}$ thick, and inner walls $500 \mathrm{~mm}$ thick. The foundations were particularly strong: $1.1 \mathrm{~m}$ wide, and the lower part of the walls were $750 \mathrm{~mm}$ thick to a height of $750 \mathrm{~mm}$. A small concreted entrance was found on the west wall, almost centrally located. The entrance was $1.06 \mathrm{~m}$ wide and had two well-preserved door jambs and a brick and flagged-stone base. A wider entrance was found on the south wall, near the southwest corner, but this opening may have been made in the later half of the nineteenth century. It was $2.1 \mathrm{~m}$ wide. The ground floor had been divided in half by a wall $460 \mathrm{~m} \mathrm{~m}$ thick, aligned approximately north to south. The west side was divided by a corridor (1.06m wide) leading from an entrance on the west side of the building. The east side, was divided into two main rooms, each measuring $4.57 \mathrm{~m}$ by $6.86 \mathrm{~m}$. Foundations of a small room $(2.59 \mathrm{~m}$ by $1.52 \mathrm{~m})$, found towards the centre of the building in the northeast quadrant, with walls as thick as the exterior walls was assumed to be an arsenal.

${ }^{84}$ Davis "A Note on the Excavation of the Barracks at Paremata" p 29.
Cemented stone foundations were found in some places, as well as rubble foundation. Sand (a width of $0.38-0.45 \mathrm{~m}$ ) had been packed against the exterior of the foundations. Small rectangular holes, thought to be joist holes for the support of wooden flooring, were found on the inside of the main walls, $0.38-0.46 \mathrm{~m}$ above the foundations. Seven window embrasures, splaying out on the inside, were found on the exterior walls. Presumably there were eight originally, as the wall had been broken in the expected position of the eighth, in the northeast corner. The embrasures were $1.77 \mathrm{~m}$ wide with brick facings and a concrete step $0.3 \mathrm{~m}$ above the foundations. Part of the northern wall of the southeast tower was standing, but there was no surface evidence of the northwest tower. However, excavations exposed the tower foundations, and each measured $4.57 \mathrm{~m}$ square. A brick platform for a try pot was found against the northern wall of the southeast tower and the east wall of the main building. ${ }^{85}$

It was found that the barracks had been built over a midden. The midden is of unknown age, although it could pre-date Paremata Pā as

${ }^{85}$ Davis "A Note on the Excavation of the Barracks at Paremata" pp 25-29. it contained moa bone fragments, comprising a small worked tab and a fragment of a onepiece fish hook. ${ }^{86}$

A photograph taken about 1890 show shows the ruins of the barracks covered with a corrugated iron roof converting them into farm buildings. ${ }^{87}$ ${ }^{86}$ Davis "A Note on the Excavation of the Barracks at
Paremata" p 28.
${ }^{87}$ Crompton-Smith Collection G-27075-1/2 Alexander
Turnbull Library, Wellington, New Zealand. 


\section{REFERENCES}

Archsite 2010. New Zealand Archaeological Association's

Archaeological site Recording Scheme website. www.archsite.org.nz

Ballara, Angela "Te Whanganui-a-Tara: Phases of Maori occupation of Wellington harbour c. 1800-1840" The Making of Wellington ed. David Hamer \& Roberta Nicholls Wellington: Victoria University Press, 1990: 9-34.

Bassett, Judith "Impotent Autocrats 1840-1860" The People and the Land Te Tangata me Te whenua. An Illustrated History of New Zealand 1820-1920 ed. Judith Binney, Judith Bassett \& Erik Olssen Wellington: Allen \& Unwin, 1990:57-76.

Best, Elsdon "Old Redoubts, Blockhouses, and Stockades of the Wellington District" Transactions of the New Zealand Institute (1921) 53:14-28.

Burnett, R.I.M. The Paremata Barracks [National Historic Places Trust New Zealand Bulletin 4] Wellington: Government Printer in conjunction with National Historic Places Trust, 1963.

Collinson, T.B. "Plan-of The Government Reserve at Paramatta-Point Near Wellington New Zealand, being part of Section No. 81 Porirua District" 1848. MapColl--c832.47961gbbd/1848/Acc.43553, Alexander Turnbull Library, Wellington. http://natlib.govt.nz/records/23134245 Collinson, T.B. "Report of the Earthquake of October 1848, at Paremata Point, Porirua, near Wellington" 18 November 1848 (Manuscript copy) Despatch No 118 Wellington November 211848 From Lieut Governor Eyre to H.E. the Governor in Chief Transmitting report on Barrack at Porirua G7/3 Archives New Zealand, Wellington.

Crompton-Smith Collection G-27075-1/2 Alexander Turnbull Library, Wellington.

Davis, Susan "A Note on the Excavation of the Barracks at Paremata" The Paremata Barracks ed. R.I.M. Burnett Wellington: Government Printer, in conjunction with National Historic Places Trust [National Historic Places Trust New Zealand Bulletin 4], 1963:25-29.

Fitzgerald, T.H. "Calling for an investigation on the origin of the fire at Porirua Barracks". Letter dated 24 August 1847 from T.H. Fitzgerald to S.E.Grimstone with a note from J.E. Eyre to Mr Grimstone dated 28 August 1847. NM8/20, Record no.: 1847/552 Archives New Zealand, Wellington.

Fitzgerald, T.H. "Enclosing a letter from James Wilson relative to the completion of Porirua Barracks" Letter dated 4 August 1847 from T.H. Fitzgerald to the Superintendent, Wellington. NM8/19, Record no.: 1847/514 Archives New Zealand, Wellington.

Fitzgerald, T.H. "Enclosing a letter from James Wilson that the payment of $£ 350$ may be made in advance at the completion of Porirua Barrack." Letter dated 13 August 1847 from T.H. Fitzgerald to S.E. Grimstone. CS1/2, Record no.: 47/446 Archives New Zealand, Wellington.

Fitzgerald, T.H. "Plans and specifications of the Military Barracks at Porirua." Letter dated 30 May 1846 from Thomas Henry Fitzgerald, Assistant Surveyor, to [?Hansen] the Superintendant, Wellington. CS1/2, Record no.: 46/2761 Archives New Zealand, Wellington.

Fitzgerald, T.H. "Possession of the receipt from the Acting Barracks Master for the Barracks Porirua." Letter dated 9 August 1847 from T.H. Fitzgerald to S.E. Grimstone. CS1/2, Record no.: 47/424 Archives New Zealand, Wellington.

Fitzgerald, T.H. "Requesting further investigation as to the valuation of Porirua Buildings." Letter dated 16 June 1852 from T.H. Fitzgerald to Colonial Secretary Wellington. CS1/2, Record no.: 52/798 Archives New Zealand, Wellington.

Fitzgerald, T.H. (surveyor) "Sketch plan shewing Tom's claim" Survey 
office plan SO 10505, 1843. WNC_SO_10505_I_1, QuickMap, Custom Softwate Ltd. http://www.quickmap.co.nz

Fitzgerald, T.H. "Soliciting extension of leave for Mr Wilson to complete the barracks at Porirua." Letter dated 8 February 1847 from T.H. Fitzgerald to Superintendent in Wellington NM8/16, Record no.: 1847/98 Archives New Zealand, Wellington.

Fordyce, Linda The Pa of Porirua 1830-1850 Porirua, Pataka Museum of Arts and Cultures, 2010. http://www.pataka.org.nz/wpcontent/uploads/The-Pa-of-Porirua-11.pdf.

"Government Notice: To builders, stone-masons, \&c." The Wellington Independent (29 April 1846):2.

Grapes, R.H. and G.R. Holdgate "Earthquake clustering and possible fault interactions across Cook Strait, New Zealand, during the 1848 and 1855 earthquakes" New Zealand Journal of Geology and Geophysics (2014) 57(3):312-330

Grey, G. "Extract from a Letter of His Excellency the Governor to Major Last dated Wellington 21 April/46". 4 May 1846 Supt. of S. Division Minutes of His Excellency - For information regarding Barrack at Porirua $N^{o}$ 20 From: Mathew Richmond, Superintendent of the Southern Division, Wellington to Colonial Secretary, Auckland. IA1 Box/Item 49, Record no. 1846/731 Archives New Zealand, Wellington.

Grey, G. "Secret. Memorandum" April 191846 Enclosure No 2 Despatch No 36 Wellington April 221846 Grey, Lt Governor to the Right Honorable Lord Stanley pp 817-839 G30/9 Archives New Zealand, Wellington.

Grey, G. "The occupation of Porirua by the Military, Completion of Roads". Memorandum dated 15 April 1846. CS1 Box/Item: 2, Record no.: 46/211, Archives New Zealand, Wellington.

Healy, W.B. (co-ordinator) "Pauatahanui Inlet: an environmental study" DSIR Information Series 141 Wellington: Science Information Division, DSIR, 1980.
Heritage New Zealand Pouhere Taonga Act 2014. http://www.legislation.govt.nz/act/public/2014/0026/latest/whole.html \#DLM4005414

Heritage New Zealand Pouhere Taonga "Heritage New Zealand List/ Rārangi Kōrero" http://www.historic.org.nz/

McKillop, H.F. Reminiscences of twelve months' service in New Zealand as a midshipman, during the late disturbances in that colony London: Richard Bentley, 1849

McManaway, V.D. 1852 MapColl 832.47hkcmf 18524443 Alexander Turnbull Library, Wellington.

"Military movements connected with Rangihaeata" The Wellington Independent (15 April 1846):3.

Mundy, G.C. "Military Post on Porirua Harbour" January 1848. A-161016, Alexander Turnbull Library, Wellington, New Zealand. http://natlib.govt.nz/records/23221818

Mundy, G.C. Our Antipodes London: Richard Bentley, 1852

New Zealand Historic Places Trust Pouhere Taonga "The Register." http://www.historic.org.nz/TheRegister

"New Zealand Spectator, and Cook's Strait Guardian. Wednesday, May 27, 1846" New Zealand Spectator, and Cook's Strait Guardian (27 May 1846):2.

"New Zealand Spectator, and Cook's Strait Guardian. Saturday, August 1, 1846" New Zealand Spectator, and Cook's Strait Guardian (1 August 1846):2.

"New Zealand Spectator, and Cook's Strait Guardian. Saturday, August 14, 1847" The New Zealand Spectator, and Cook's Strait Guardian (14 August 1847):2.

Ngāti Toa Rangatira, and Trustee of the Toa Rangatira Trust and The Crown Deed of settlement of Historical Claims [signed 7 December, 2012]. Wellington, Office of Treaty Settlements - Te Tari Whakatau Take e pa 
ana ki te Tiriti o Waitangi, Wellington. http://www.ots.govt.nz/. Ngāti Toa Rangatira, and Trustee of the Toa Rangatira Trust and The Crown Deed of Settlement Schedule: Documents. Wellington, Office of Treaty Settlements - Te Tari Whakatau Take e pa ana ki te Tiriti o Waitangi, 2012. http://www.ots.govt.nz/.

Office of Ordnance [signatures illegible] "Office of Ordnance requesting that the Military buildings at Porirua may be surveyed and amount paid to Ordnance." Letter dated 26 May 1852 from Office of Ordnance to the Colonial Secretary. CS1/2, Record no.: 52/679 Archives New Zealand, Wellington.

"Official account of the capture of Rauparaha, and subsequent proceedings against the rebels" Nelson Examiner and New Zealand Chronicle (5 September 1846):106.

Porirua City District Plan "Plan Change 15: Historic Heritage: Replacement of all heritage provisions with a specific historic heritage chapter, and consequential amendments" Operative 31 March 2014 http://www.pcc.govt.nz/Publications/District-Plan/Plan-Change-15

Power, W.T. Sketches in New Zealand with pen and pencil. From a Journal kept in that Country from July 1846, to June 1848 London: Longman, Brown, Green, and Longmans, 1849.

Reilly, Helen Pāuatahanui: a local history Pāuatahanui: Pāuatahanui Residents Association, 2013.

Swainson, G.M. William Swainson F.R.S., F.L.S.: Naturalist \& Artist: family letters $\mathcal{E}$ diaries, 1809-1855 Palmerston North: Geoffrey Swainson, 1992

Swainson, William and William John Swainson "Paremata Redoubt drawn about 1847." NON-ATL-P-0118, Alexander Turnbull Library, Wellington, New Zealand. http://natlib.govt.nz/records/22891844

Taylor, Richard Journal of Rev. Richard Taylor (typescript) 12 March 1847 31 December 1848, v 5 qMS-1989 Alexander Turnbull Library, Wellington.
Waitangi Tribunal "Te Whanganui a Tara me ona Takiwa. Report on the Wellington District" Waitangi Tribunal Report Wai 145 Wellington, Legislation Direct, 2003. http://www.waitangitribunal.govt.nz/scripts/reports/145/

Wakefield, Edward Jerningham Adventure in New Zealand, from 1839 to 1844; with some account of the beginnings of the British colonization of the islands London: John Murray, 1845.

Walton, Anthony "New Zealand redoubts, stockades and blockhouses, 1840-1848" DOC Science Internal Series 122 Wellington: Department of Conservation, 2003.

Ward, Louis E. Early Wellington Auckland: Whitcombe \& Tombs Limited, 1928.

"The Wellington Independent Wednesday, April 22, 1846" The Wellington Independent (22 April 1846):2.

"The Wellington Independent, Saturday, September 12, 1846" The Wellington Independent (12 September 1846):2.

Wilson, James "Requesting payment for completion of barracks." Letter dated 12 August 1847 from James Wilson to T.H. Fitzgerald. Wellington CS1/2, Record no.: 47/447. 